\title{
Dusts from dry off-gas cleaning: comparison of flowability determined by angle of repose and with shear cells
}

\author{
Christof Lanzerstorfer ${ }^{1}$
}

Received: 27 September 2016 / Published online: 18 July 2017

(C) The Author(s) 2017. This article is an open access publication

\begin{abstract}
The flowability of the dust separated in dry offgas cleaning systems is an important characteristic for the design of dust storage and conveying equipment. The angle of repose is often used as an indicator for the flowability of granular material. In this study the results for the flowability obtained from the angle of repose and by the ratio of the consolidation stress to the unconfined yield strength were compared for 77 dusts from various dry off-gas cleaning systems. For dust with a Sauter mean diameter of $>5 \mu \mathrm{m}$ the flowability indicated by the angle of repose and the results of a shear test performed at a low pre-shear load correlated reasonably. For dusts with a smaller particle size such a correlation did not exist. The values of the angle of repose were scattered with no relation to the results of the shear test. The dependence of the angle of repose on the $\mathrm{d}_{32}$ described in the literature was confirmed for the coarser dusts only. For dusts with a smaller particle size such a relationship does not exist. For very fine dusts the angle of repose was even smaller. This effect was attributed to the visible small agglomerates formed during the angle of repose measurement. These agglomerates rolling down the slope prevented the formation of a steeper cone which limits the angle of repose.
\end{abstract}

Keywords Dust flowability $\cdot$ Angle of repose $\cdot$ Shear tests

Christof Lanzerstorfer

c.lanzerstorfer@fh-wels.at

1 School of Engineering/Environmental Sciences, University of Applied Sciences Upper Austria, Stelzhamerstraße 23, 4600 Wels, Austria

\section{Introduction}

The flowability of the dust separated in dry off-gas cleaning systems is an important characteristic for the design of dust storage and conveying equipment. After separation from the off-gas, the fine granular material has to be discharged safely from the hoppers of the dust separators and then conveyed to silos for storage. Subsequently, the material has to be discharged from the silo again for further treatment, utilisation or transport to landfill sites.

In advanced bulk solids testing, shear testers are used for the investigation of the flow characteristics. The first shear tester designed for bulk solids testing was the translational shear tester developed by Jenike [1]. Some years later the first ring shear testers were designed. In shear tests the yield loci are determined for various normal stress loads at pre-shear. For each yield locus corresponding values of the consolidation stress $\sigma_{1}$ and the unconfined yield strength $\sigma_{\mathrm{c}}$ can be determined. The $\mathrm{ff}_{\mathrm{c}}$ value which is the ratio of $\sigma_{1}$ to $\sigma_{\mathrm{c}}$ provides a quantitative characterization of the flowability of a powder [2]. The larger the $\mathrm{ff}_{\mathrm{c}}$ is, the better a powder flows. The classification used to define flow behaviour consists of five categories: not flowing: $\mathrm{ff}_{\mathrm{c}}<1$; very cohesive: $1<\mathrm{ff}_{\mathrm{c}}<2$; cohesive: $2<\mathrm{ff}_{\mathrm{c}}<4$; easyflowing: $4<\mathrm{ff}_{\mathrm{c}}<10$, and free-flowing: $10<\mathrm{ff}_{\mathrm{c}}$ [3]. The flowability of most powders depends on the consolidation stress. Usually, better flowability will be obtained at a higher consolidation stress. For the design of powder storage and conveying equipment the data obtained by shear tests are required.

The flowability of a granular material can also be characterized roughly by the angle of repose [4]. Seven flowability categories ranging from very, very poor to good free flow are defined according to the United States Pharmacopeial Convention USP 29-NF24 (as cited in [5]). The instrument for the 
measurement of the angle of repose is comparatively simple and performing the measurements is easy. The basic principle of most methods is measuring the height and the diameter of the base of a cone, which is obtained by allowing a sample to fall through a fixed distance from a defined funnel onto a horizontal base plate. Various standards are available for the measurement, e.g.: ISO 4324 [6], ISO 8398 [7], ÖNORM EN 12047 [8] or ASTM D6393 [9].

Wouters and Geldart [10] reported a dependence of the angle of repose on the Sauter mean diameter $\mathrm{d}_{32}$ of the particle size distribution of various tested materials $\left(\mathrm{d}_{32}\right.$ from 8 to $113 \mu \mathrm{m}$ ). Such a dependence was also shown for other granular materials like glass beads (size range from 20 to $170 \mu \mathrm{m}$ ) by Wong [11], for a flame retardant filler ( $\mathrm{d}_{32}$ from 6 to $63 \mu \mathrm{m}$ ) by Geldart et al. [4,12] or for pulverized coal (size range from 12.5 to $137.5 \mu \mathrm{m}$ ) by Wang et al. [13]. For all materials tested, the value of the angle of repose was higher for materials with a smaller particle size. For single materials quite good correlations were found for the angle of repose and the particle size [4]. However, for different materials the curves differed substantially [10].

The angle of repose measured for a granular material depends on the measuring method and the operator. This is because the measurement technique shows limited repeatability and reproducibility which, in part, can be ascribed to the operator [14]. Rousé [15] compared six methods for measuring the angle of repose. Using various samples of sand as test material the repeatability of the values of the angle of repose was very good (95\% of the values having a dispersion of less than $1.5^{\circ}$ ). However, the measured angle of repose varied significantly from method to method. Wang et al. [13] compared three different measuring methods for the angle of repose by testing pulverized coal. They, too, found some differences in the results measured with the various methods.

The aim of this study was to investigate whether measurement of the angle of repose can provide an indicator for a rough assessment of the flowability of dusts from dry offgas cleaning systems. The flowability of 28 residues from dry off-gas de-dusting systems at power plants, steelmaking plants, non-ferrous metallurgical plants and mineral processing plants was characterized by the angle of repose and with shear tests. For the comparison also previously published data of another 49 dusts from dry off-gas de-dusting systems at cement mills, ironmaking plants and biomass combustion plants were considered.

\section{Materials and methods}

\subsection{Residues}

The dust samples investigated were collected from the dry off-gas cleaning systems of various industrial processes (power plants using various types of fuels, steelmaking plants, non-ferrous metallurgical plants and mineral processing plants). The process plants and the types of de-dusting systems where the dust samples originate from are summarized in Table 1 . Approximately $2 \mathrm{dm}^{3}$ of each dust were taken at the dust discharge outlets of the respective dedusting units. The volume of each sample was reduced to an amount suitable for the various laboratory tests using sample dividers which were applied repeatedly (Haver RT 12.5, Quantachrome Micro Riffler).

For dust samples from iron ore sinter plants, blast furnaces, cement mills and district heating plants using solid biomass as fuel data from shear tests, for the angle of repose and for the particle size distribution are already available in the literature [16-22].

\subsection{Measurements}

For the shear tests a Schulze ring shear tester, type RST-XS, was used. The measurements were performed at the lowest and highest possible value for the vertical load during sample consolidation in the pre-shear step, $600 \mathrm{~Pa}$ and 20,000 $\mathrm{Pa}$, respectively. The calibration of the ring shear tester was verified at a normal stress of $3000 \mathrm{~Pa}$ at pre-shear using the certified reference material BCR-116 from the Community Bureau of Reference (Limestone Powder). This material was also used in a round robin test on ring shear testers [23]. The measured values of the shear stress were in the range of the reported mean shear stress $\tau_{\mathrm{m}} \pm 0.6$ times the reported standard deviation s.

The angle of repose of the dust samples was measured according to ISO 4324 [6]. A cone of material was obtained by passing the dust through a special funnel placed at a certain height above a flat and level circular plate. The base angle of the cone was calculated from the diameter of the base plate and the height of the cone. The average angle of repose and the standard deviation were calculated from five measurements carried out for each dust. The scale of the instrument is in millimeters. The closest value was used for the reading. The accuracy of the reading is thus limited to $\pm 0.5 \mathrm{~mm}$.

The particle size distribution of the dust samples was measured using a Sympatec HELOS/RODOS laser diffraction instrument with dry sample dispersion. For the verification of the calibration of the instrument a SiC-P600'06 standard from Sympatec was used. The target value for the mass median diameter $\mathrm{d}_{50}$ of the standard is $25.59 \mu \mathrm{m}$, the acceptable range is 24.82 to $26.36 \mu \mathrm{m}$. The measured value for the $\mathrm{d}_{50}$ was $25.62 \mu \mathrm{m}$. The Sauter mean diameter $\mathrm{d}_{32}$ of the dusts was calculated from the particle size distribution.

The moisture content of the dust samples was measured gravimetrically. The dust samples were dried at $105^{\circ} \mathrm{C}$ until a constant weight was reached. 
Table 1 Dust samples: sources and measured properties

\begin{tabular}{|c|c|c|c|c|c|c|}
\hline \multirow[t]{3}{*}{ Dust sample } & \multirow{3}{*}{$\begin{array}{l}\text { Process where the } \\
\text { dust originates from }\end{array}$} & \multirow{3}{*}{$\begin{array}{l}\text { Gas cleaning } \\
\text { system }\end{array}$} & \multirow[t]{3}{*}{$\mathrm{d}_{32}$ in $\mu \mathrm{m}$} & \multicolumn{2}{|l|}{$\mathrm{ff}_{\mathrm{c}}$} & \multirow{3}{*}{$\begin{array}{l}\text { Angle of repose }{ }^{\mathrm{a}} \text { in }^{\circ} \\
\text { Arithmetic mean } \pm \text { standard } \\
\text { deviation }\end{array}$} \\
\hline & & & & \multicolumn{2}{|c|}{ Pre-shear load } & \\
\hline & & & & $600 \mathrm{~Pa}$ & $20,000 \mathrm{~Pa}$ & \\
\hline \multicolumn{7}{|l|}{ Power plant } \\
\hline A & Fuel: coal; $420 \mathrm{MW}_{\text {th }}$ & ESP & 6.68 & 3.1 & 5.7 & $43.7 \pm 0.7$ \\
\hline $\mathrm{B}$ & $\begin{array}{l}\text { Fuel: bituminous coal; } \\
120 \mathrm{MW}_{\text {th }}\end{array}$ & $\begin{array}{l}\text { Dry desulphurization } \\
\text { with } \mathrm{Ca}(\mathrm{OH})_{2} \text {, fabric } \\
\text { filter }\end{array}$ & 4.50 & 0.93 & 1.25 & $49.9 \pm 0.3$ \\
\hline $\mathrm{C}$ & Fuel: rubber tree; $50 \mathrm{MW}_{\text {th }}$ & ESP & 1.42 & 1.32 & 1.95 & $52.2 \pm 0.5$ \\
\hline $\mathrm{D}$ & Fuel: wheat straw; $45 \mathrm{MW}_{\text {th }}$ & Fabric filter & 1.08 & 1.35 & 1.00 & $43.4 \pm 0.6$ \\
\hline $\mathrm{E}$ & Fuel: forest residue; $10 \mathrm{MW}_{\text {th }}$ & ESP & 1.69 & 1.20 & 1.67 & $55.6 \pm 0.3$ \\
\hline $\mathrm{F} 1$ & $\begin{array}{l}\text { Fuel: sewage sludge; oil sludge } \\
\text { and acid tar; } 22.5 \mathrm{MW}_{\text {th }}\end{array}$ & Cyclone & 9.74 & 5.9 & 7.0 & $37.9 \pm 0.6$ \\
\hline $\mathrm{F} 2$ & & $\begin{array}{l}\text { Dry desulphurization with } \\
\mathrm{NaHCO}_{3} \text {, fabric filter }\end{array}$ & 2.16 & 1.73 & 3.0 & $53.5 \pm 0.6$ \\
\hline G1 & $\begin{array}{l}\text { Fuel: plastic waste and sewage } \\
\text { sludge; } 110 \mathrm{MW}_{\text {th }}\end{array}$ & Cyclone & 9.76 & 2.9 & 9.1 & $46.7 \pm 0.3$ \\
\hline $\mathrm{G} 2$ & & Fabric filter & 3.35 & 1.34 & 3.0 & $51.9 \pm 0.6$ \\
\hline \multicolumn{7}{|l|}{ Steel mill } \\
\hline $\mathrm{H} 2$ & $\begin{array}{l}\text { Electric arc furnace (primary } \\
\text { and secondary off-gas) }\end{array}$ & $\begin{array}{l}\text { Fabric filter (after baffle } \\
\text { separator) }\end{array}$ & 0.83 & 1.31 & 1.59 & $46.4 \pm 0.8$ \\
\hline $\mathrm{I} 2$ & $\begin{array}{l}\text { Electric arc furnace (primary } \\
\text { and secondary off-gas) }\end{array}$ & $\begin{array}{l}\text { Fabric filter (after baffle } \\
\text { separator) }\end{array}$ & 0.98 & 1.64 & 2.0 & $48.8 \pm 0.6$ \\
\hline J1a & $\begin{array}{l}\text { Electric arc furnace (primary } \\
\text { and secondary off-gas) }\end{array}$ & $\begin{array}{l}\text { Baffle separator (drop out } \\
\text { box) }\end{array}$ & 26.9 & 12 & 20 & $36.6 \pm 0.9$ \\
\hline $\mathrm{J} 1 \mathrm{~b}$ & & Spray cooler & 10.7 & 8.5 & 11 & $37.4 \pm 0.4$ \\
\hline $\mathrm{J} 2$ & & Fabric filter & 1.08 & 1.67 & 1.44 & $43.0 \pm 0.7$ \\
\hline $\mathrm{K}$ & Vacuum degassing & Fabric filter & 1.49 & 2.2 & 1.80 & $42.7 \pm 0.6$ \\
\hline $\mathrm{L}$ & Vacuum degassing & Fabric filter & 1.22 & 2.3 & 2.4 & $44.1 \pm 0.4$ \\
\hline M2 & $\begin{array}{l}\text { Basic oxygen furnace } \\
\text { (converter) }\end{array}$ & ESP (after spray cooler) & 0.74 & 1.43 & 1.88 & $47.5 \pm 0.5$ \\
\hline $\mathrm{N} 1$ & $\begin{array}{l}\text { Basic oxygen furnace } \\
\text { (converter) }\end{array}$ & Spray cooler & 9.44 & 4.6 & 4.3 & $38.6 \pm 1.2$ \\
\hline $\mathrm{N} 2$ & & ESP & 0.72 & 1.99 & 2.4 & $50.5 \pm 0.5$ \\
\hline $\mathrm{O}$ & Converter shop ventilation & Fabric filter & 3.23 & 1.71 & 1.88 & $51.6 \pm 0.2$ \\
\hline $\mathrm{P}$ & Converter shop ventilation & Fabric filter & 2.96 & 1.53 & 2.2 & $50.7 \pm 0.4$ \\
\hline \multicolumn{7}{|c|}{ Non-ferrous metallurgical processes } \\
\hline Q1 & Copper smelter, shaft furnace & Baffle separator & 38.1 & 10 & 8.5 & $37.1 \pm 1.0$ \\
\hline Q2 & & Fabric filter & 1.08 & 1.70 & 2.7 & $40.2 \pm 0.7$ \\
\hline $\mathrm{R}$ & $\begin{array}{l}\text { Copper smelter, shop } \\
\text { ventilation }\end{array}$ & Fabric filter & 1.22 & 1.33 & 1.84 & $48.2 \pm 0.3$ \\
\hline $\mathrm{S}$ & $\begin{array}{l}\text { Copper smelter, shop } \\
\text { ventilation }\end{array}$ & Fabric filter & 0.61 & 2.2 & 1.87 & $42.2 \pm 0.9$ \\
\hline $\mathrm{T}$ & Aluminium smelter & Fabric filter & 1.93 & 1.98 & 3.3 & $51.6 \pm 0.2$ \\
\hline $\mathrm{U}$ & Barton reactor (lead oxide dust) & Fabric filter & 2.65 & 1.10 & 2.7 & $54.5 \pm 0.7$ \\
\hline \multicolumn{7}{|c|}{ Minerals industry } \\
\hline $\mathrm{V}$ & Lime burning shaft furnace & Fabric filter & 5.88 & 1.50 & 3.5 & $52.6 \pm 0.4$ \\
\hline
\end{tabular}

${ }^{\mathrm{a}}$ The accuracy of the reading of the height of the cone of $\pm 0.5 \mathrm{~mm}$ corresponds with a accuracy of the angle of repose of $\pm 0.2^{\circ}-0.4^{\circ}$, depending on the value of the height (the accuracy of the angle of repose improves with the height) 


\section{Results and discussion}

\subsection{Flowability and Sauter mean diameter}

The $d_{32}$ of the dusts, the angle of repose and the calculated values of $\mathrm{ff}_{\mathrm{c}}$ for a pre-shear load of 600 and 20,000 $\mathrm{Pa}$ are summarized in Table 1. Figure 1 shows the angle of repose in dependence of the $d_{32}$ for the materials investigated in this study and for the previously investigated dusts (for sinter plants: [16,17,22]; for blast furnaces: [19]; for cement mills: $[18,21]$ and for biomass combustion plants: [20]). For the coarser dusts with a $\mathrm{d}_{32}$ larger than approximately $3 \mu \mathrm{m}$ a correlation between the angle of repose and the $\mathrm{d}_{32}$ is evident. In comparison to correlation functions available in the literature for various materials in the size range from approximately 6 to $100 \mu \mathrm{m}[4,10]$ the function found in this study is less steep. The correlation coefficient $\mathrm{r}^{2}$ of 0.77 is in a similar range as reported by Wouters and Geldart [10] for catalyst particles but much lower than found for a flame retardant filler [4]. However, due to the variety of dusts included, a less expressed correlation has to be expected. For the fine dusts with a $\mathrm{d}_{32}$ of less than approximately $3 \mu \mathrm{m}$ no correlation was found. The data points even suggest that for very fine dusts the value of the angle of repose tends to be smaller. Figure 2 shows a picture of a measurement of the angle of repose with such a fine dust (dust H2). At the lower part of the cone and in the area around the cone agglomerates of the dust are visible. These agglomerates form when the added material slides down the material cone. The agglomerates rolling down the slope prevented the formation of a steeper cone.

In Fig. 3, the Sauter mean diameter and the $\mathrm{ff}_{\mathrm{c}}$ of the dusts at $600 \mathrm{~Pa}$ are shown. A certain correlation between the two parameters is visible: a better flowability is correlated with

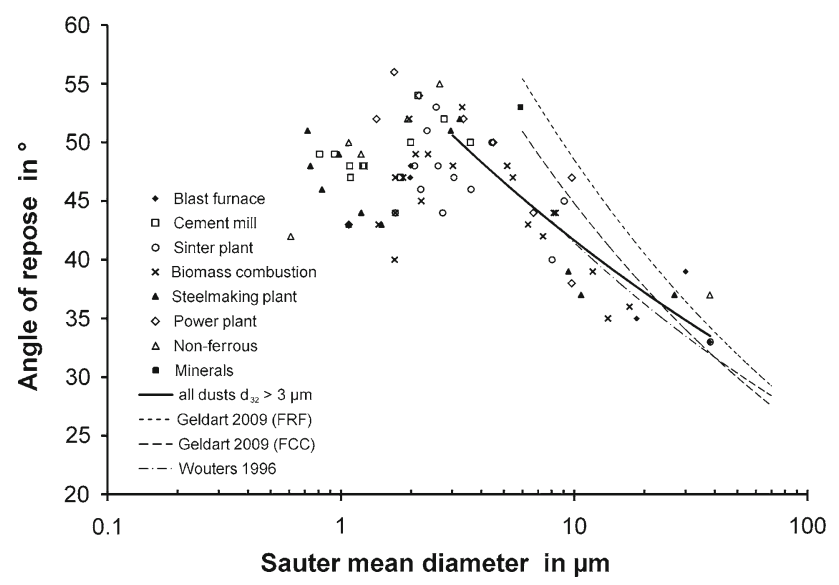

Fig. 1 Angle of repose as a function of the Sauter mean diameter of the dusts (Blast furnace: [19]; Cement mill: [18,21]; Sinter plant: [16,17,22]; biomass combustion: [20])

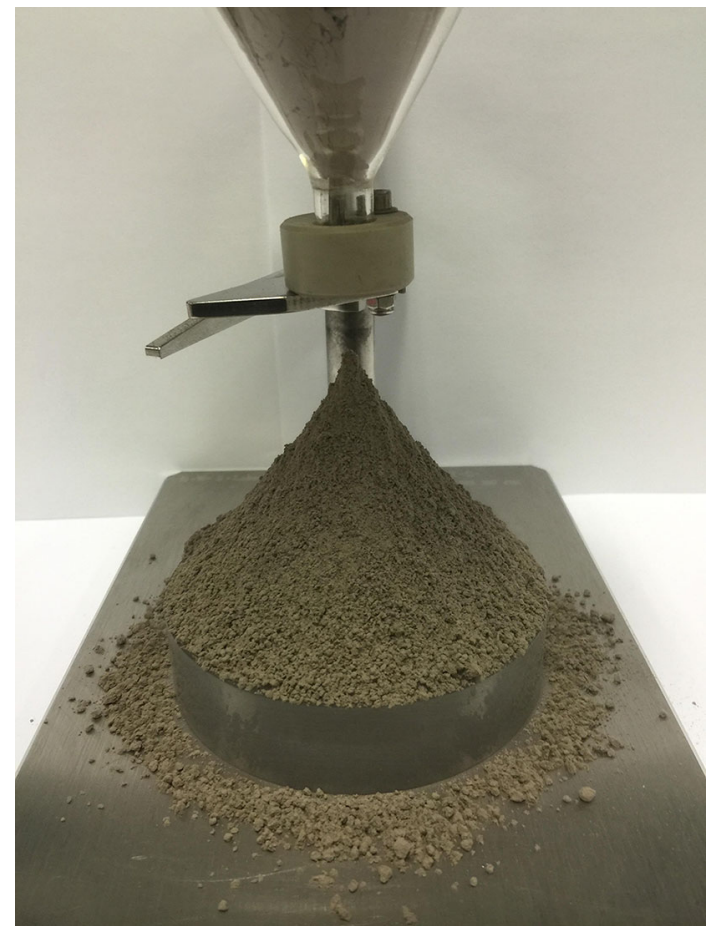

Fig. 2 Angle of repose neasurement of dust $\mathrm{H} 2$

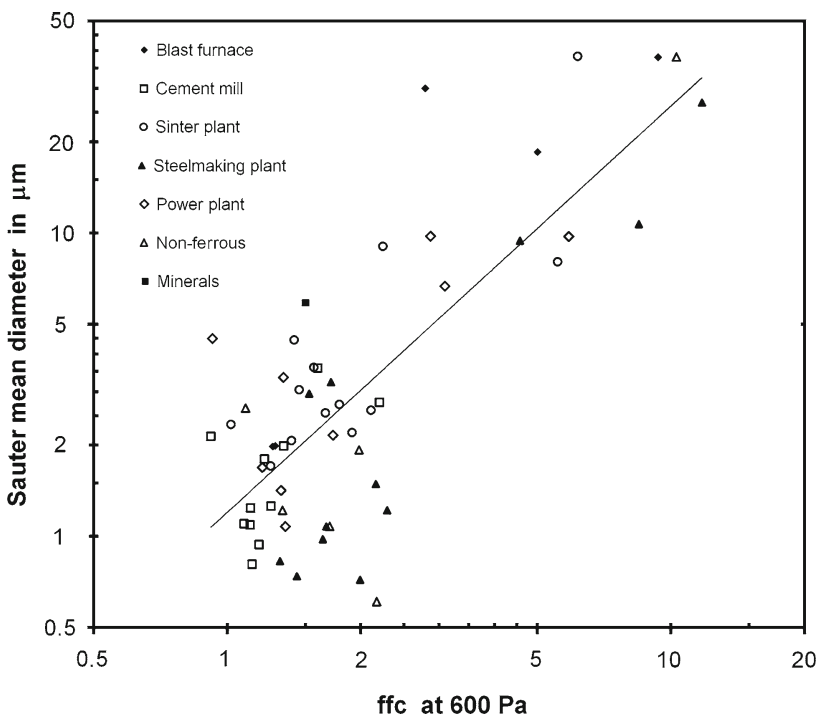

Fig. 3 Sauter mean diameter versus $\mathrm{ff}_{\mathrm{c}}$ of the dusts at $600 \mathrm{~Pa}$ (blast furnace: [19]; cement mill: [18,21]; sinter plant: [16,17,22]; biomass combustion: [20])

a coarser dust size. However, the correlation is rather weak (correlation coefficient 0.61 ).

\subsection{Correlation of flowability scales}

In both flowability scales a different number of flow categories are defined. For the $\mathrm{ff}_{\mathrm{c}}$ five categories are defined while for the angle of repose there are seven categories. 
However, the names of the categories suggest a certain correspondence: The angle of repose categories "Excellent/very free flow" and "Good/free flow" were assigned to the $\mathrm{ff}_{\mathrm{c}}$ category "Free flowing". Similarily, the categories "Fair" and "Passable" were assigned to the $\mathrm{ff}_{\mathrm{c}}$-category "Easy flowing". For the remaining three categories in each scale, practically the same names are used: "Cohesive", "Very cohesive" and "Not flowing". Therefore, these categories can be assumed to be equivalent to each other. In the Figs. 4 and 5 the $\mathrm{ff}_{\mathrm{c}}$ ratio on a logarithmic scale and the angle of repose are shown on the axes. The limits of the flow categories are shown together with a virtual correlation line defined by the upper and lower limits of the corresponding categories. Additionally, two dashed lines are drawn representing a rough scattering range by adding half the width of the flowability category of one of the parameters. On the left side of Fig. 4 the correlation of the angle of repose and the $\mathrm{ff}_{\mathrm{c}}$ ratio is depicted for a pre-shear load of $600 \mathrm{~Pa}$, while on the right side the pre-shear load was 20,000 Pa.

At the low pre-shear load some correlation was found for both flowability descriptors for free flowing to cohesive dusts. Nearly all data points are within the indicated scatter range. For cohesive to very cohesive materials most of the data points are out of this range. At the higher pre-shear load for the majority of the dusts the value of $\mathrm{ff}_{\mathrm{c}}$ is higher. Therefore, many data points of the free flowing to easy flowing dusts are out of the scatter range. At the same time the very cohesive dusts are still out of the scatter range. It can be concluded that some correlation between both flowability descriptors can be found for free flowing to cohesive dusts at low pre-shear load only.
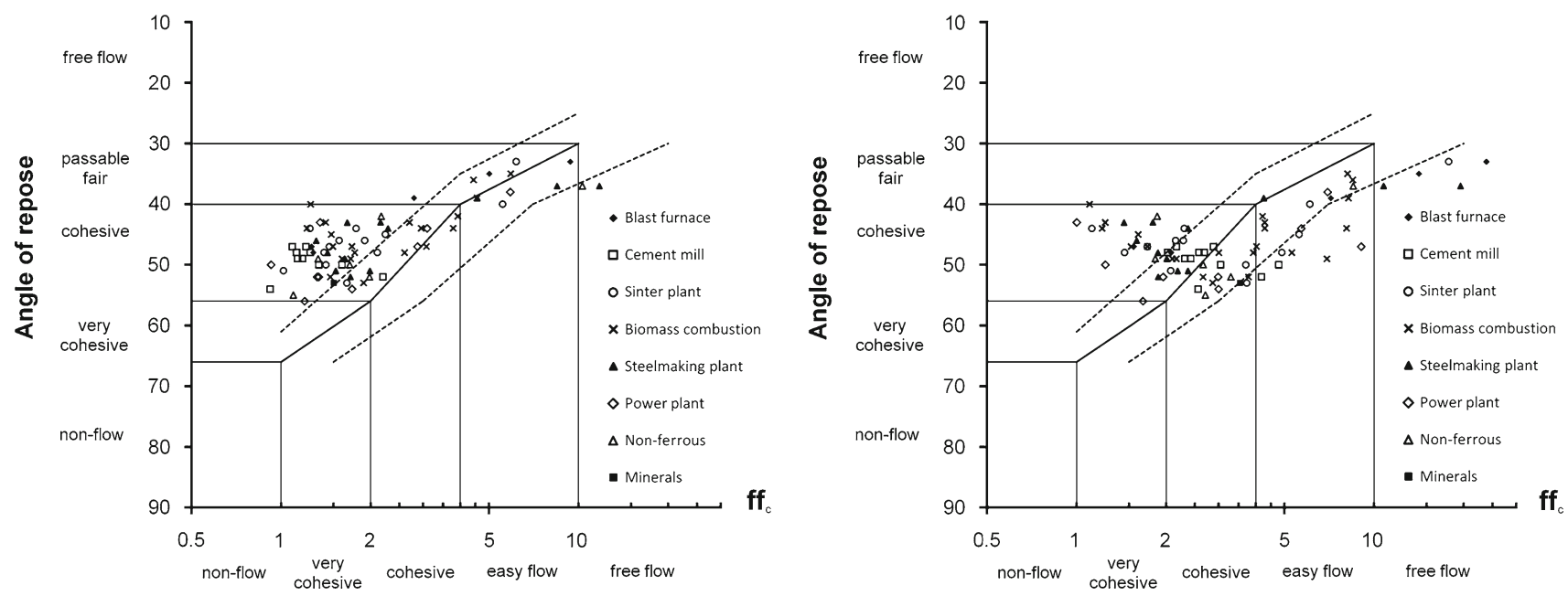

Fig. 4 Correlation of the angle of repose and the $\mathrm{ff}_{\mathrm{c}}$ ratio for a pre-shear load of $600 \mathrm{~Pa}$ (left) and 20,000 Pa (right); (blast furnace: [19]; cement mill: [18,21]; sinter plant: [16,17,22]; biomass combustion: [20])
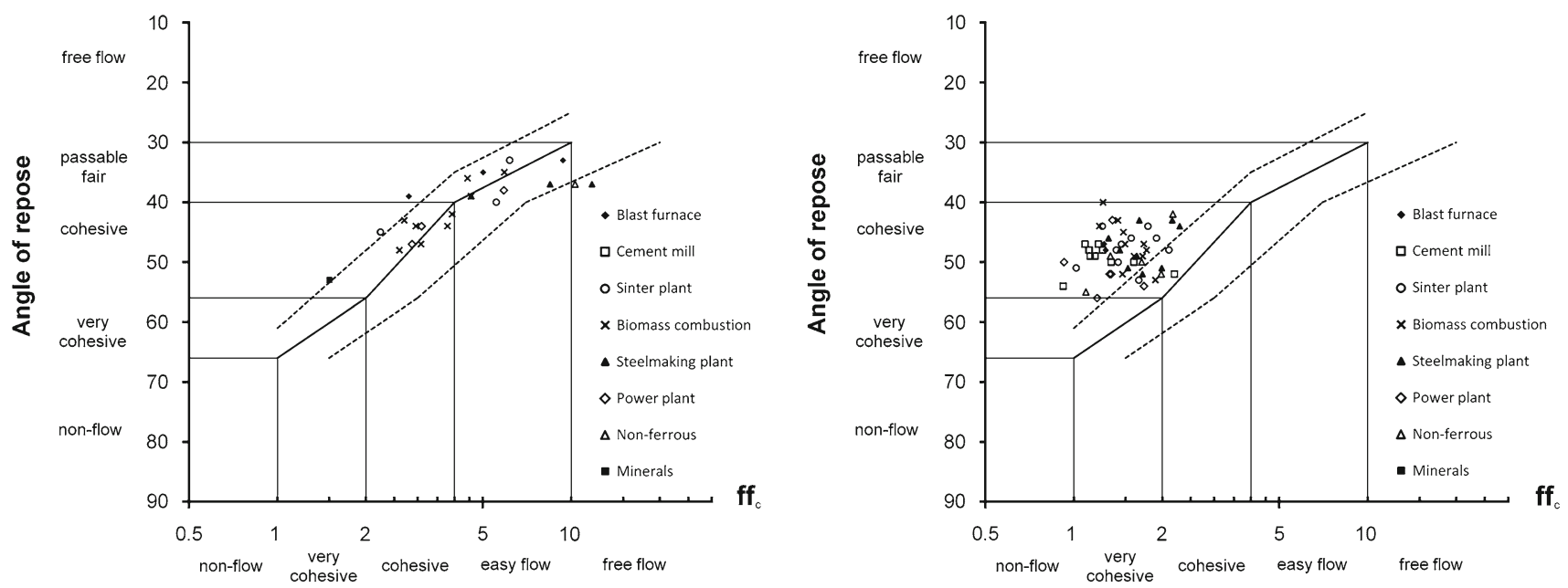

Fig. 5 Correlation of the angle of repose and the $\mathrm{ff}_{\mathrm{C}}$ ratio for a pre-shear load of $600 \mathrm{~Pa}: \mathrm{d}_{32}$ of the dust $>5 \mu \mathrm{m}($ left $)$ and $<5 \mu \mathrm{m}($ right); (blast furnace: [19]; Cement mill: [18,21]; sinter plant: [16,17,22]; biomass combustion: [20]) 
In Fig. 5 the results for a pre-shear load of $600 \mathrm{~Pa}$ are split into two groups: the data points of dusts with a $d_{32}>5 \mu \mathrm{m}$ are depicted on the left of Fig. 5, while the data points of dusts with a $\mathrm{d}_{32}<5 \mu \mathrm{m}$ are depicted on the right. In the analysis of the data it was found that a limit of approximately $5 \mu \mathrm{m}$ gives the best differentiation between the dusts whether the data points are within the scatter range or not. It is well known that other dust properties (e.g. the width of particle size distribution, the particle shape, the bulk density and the material hardness) can also affect the dust flow properties. However, it looks as if for dusts from off-gas de-dusting systems this differentiation would be possible using the $\mathrm{d}_{32}$ only.

Although there is a certain correlation for the coarser materials with $\mathrm{a}_{32}>5 \mu \mathrm{m}$ between the angle of repose and the flowability resulting from a shear test, it is impossible to obtain the required information for the design of a dust hopper outlet by measuring the angle of repose. The required data can only be obtained by shear tests $[1,2]$. However, the measurement of the angle of repose can provide a first impression of the flowability of the dust. For dusts with a $d_{32}<5 \mu \mathrm{m}$ even this information cannot be obtained by measuring the angle of repose.

\section{Conclusion}

Some correlation between the angle of repose and the $\mathrm{d}_{32}$ of a dust can be expected for dusts with a $\mathrm{d}_{32}$ of $>3 \mu \mathrm{m}$. The data resulting from the measurements for this study and from previously published studies fit quite well to correlation functions published in the literature. In contrast to this, there was no correlation found for dusts with a smaller particle size. For such dusts the angle of repose was even the lower the $d_{32}$ was. The formation of small agglomerates was the visible cause for this effect.

Although the angle of repose of a dust is not adequate for the design of the outlet of dust hoppers, etc. it is often measured to provide a rough indication of the flowability of a dust because of the simplicity of the measuring method. The analysis of the data confirmed some correlation between the angle of repose and the $\mathrm{ff}_{\mathrm{c}}$ determined by shear tests at a low pre-shear load. However, this correlation was found only for dusts with a $\mathrm{d}_{32}$ of higher than approximately $5 \mu \mathrm{m}$.

The better correlation of the results at low pre-shear load in the shear tests might result from the circumstance that during measurement of the angle of repose the stress in the material is low, too. Therefore, the two empirically derived flowability category scales - the first based on the $\mathrm{ff}_{\mathrm{c}}$ value derived from shear tests and the second based on the measurement of the angle of repose-correlate better under this condition.
The angle of repose, which is determined in a simple-tocarry-out procedure, can be used as a rough indicator for the flowability of dusts with a $\mathrm{d}_{32}$ of higher than approximately $5 \mu \mathrm{m}$. For most dusts with a smaller particle size the resulting data points were outside the rough scattering range. This is because for these fine dusts the values of $\mathrm{ff}_{\mathrm{c}}$ were lower (flowability category very cohesive) while the values of the angle of repose were still in the range of the flowability category cohesive. Thus, the angle of repose cannot be used as a flowability indicator for very fine dusts. Additionally, the angle of repose gives no indication about the flowability at higher stress values.

Acknowledgements Open access funding provided by University of Applied Sciences Upper Austria. The author wants to thank the University of Applied Sciences Upper Austria for funding the work (KSt 8813). Proofreading by D. Moser is gratefully acknowledged.

\section{Compliance with ethical standards}

Conflict of interest The author declares that he has no conflict of interest.

Open Access This article is distributed under the terms of the Creative Commons Attribution 4.0 International License (http://creativecomm ons.org/licenses/by/4.0/), which permits unrestricted use, distribution, and reproduction in any medium, provided you give appropriate credit to the original author(s) and the source, provide a link to the Creative Commons license, and indicate if changes were made.

\section{References}

1. Jenike, A.W.: Storage and Flow of Solids. Bulletin No. 123 Utah Engineering Experiment Station, 4th edn. University of Utah, Salt Lake City (1970)

2. Schulze, D.: Powders and Bulk Solids: Behavior, Characterization, Storage and Flow. Springer, Berlin (2008)

3. Schulze, D.: Measuring powder flowability: a comparison of test methods-part I. Powder Bulk Eng. 10, 45-61 (1996)

4. Geldart, D., Abdullah, E.C., Hassanpour, A., Nwoke, L.C., Wouters, I.: Characterization of powder flowability using measurement of angle of repose. China Particuol. 4, 104-107 (2006)

5. Stanley-Wood, N.: Bulk powder properties: instrumentation and techniques. In: McGlinchey, D. (ed.) Bulk Solids Handling, Equipment Selection and Operation, pp. 1-67. Blackwell Publishing, Oxford (2008)

6. ISO 4324: Surface Active Agents-Powders and GranulesMeasurement of the Angle of Repose. International Organization for Standardization, Genève (1977)

7. ISO 8398: Solid Fertilizers-Measurement of Static Angle of Repose. International Organization for Standardization, Genève (1989)

8. ÖNORM EN 12047: Feste Düngemittel-Bestimmung des statischen Schüttwinkels. Österreichisches Normungsinstitut, Wien (1996)

9. ASTM D6393: Standard Test Method for Bulk Solids Characterization by Carr Indices. ASTM International, West Conshohocken (2014)

10. Wouters, I.M.F., Geldart, D.: Characterising semi-cohesive powders using angle of repose. Part. Part. Syst. Charact. 13, 254-259 (1996) 
11. Wong, A.C.: Characterisation of the flowability of glass beads by bulk densities ratio. Chem. Eng. Sci. 55, 3855-3859 (2000)

12. Geldart, D., Abdullah, E.C., Verlinden, A.: Characterisation of dry powders. Powder Technol. 190, 70-74 (2009)

13. Wang, W., Zhang, J., Yang, S., Zhang, H., Yang, H., Yue, G.: Experimental study on the angle of repose of pulverized coal. Particuology 8, 482-485 (2010)

14. Clayton, J.: Reviewing current practice in powder testing. Org. Process Res. Dev. 19, 102-109 (2015)

15. Rousé, P.C.: Comparison of methods for the measurement of the angle of repose of granular materials. Geotech. Test. J. 37, 1-5 (2014)

16. Lanzerstorfer, C.: Mechanical properties of dust collected by the dust separators in iron ore sinter plants. Environ. Technol. 36, 31863193 (2015)

17. Lanzerstorfer, C.: Mechanical and flow properties of residue from dry desulphurization of iron ore sinter plant off-gas. Environ. Eng. Sci. 32, 970-976 (2015)
18. Lanzerstorfer, C.: Mechanical and flow properties of dusts from cement plants. Adv. Cem. Res. 28, 328-335 (2015)

19. Lanzerstorfer, C.: Mechanical properties of dust collected from blast furnace dust catchers and cast house de-dusting filters. Part. Sci. Technol. 34, 366-372 (2016)

20. Lanzerstorfer, C.: Flowability of fly ashes from grate-fired combustion of forest residues. Fuel Process. Technol. 150, 10-15 (2016)

21. Lanzerstorfer, C., Feichtinger, K.: Cement kiln dust (CKD): characterization of dust collected in the various fields of the electrostatic precipitator (ESP). Environ. Eng. Sci. 33, 200-206 (2016)

22. Lanzerstorfer, C., Steiner, D.: Characterization of sintering dust collected in the various fields of an electrostatic precipitator. Environ. Technol. 37, 1559-1567 (2016)

23. Schulze, D.: Round robin test on ring shear testers. Adv. Powder Technol. 22, 197-202 (2011) 